\title{
Preventing vertical HIV virus transmission: hospital care assessment
}

\author{
Prevenção da transmissão vertical do vírus HIV: avaliação da assistência hospitalar \\ Prevención de la transmisión vertical del virus del VIH: evaluación de la asistencia hospitalaria
}

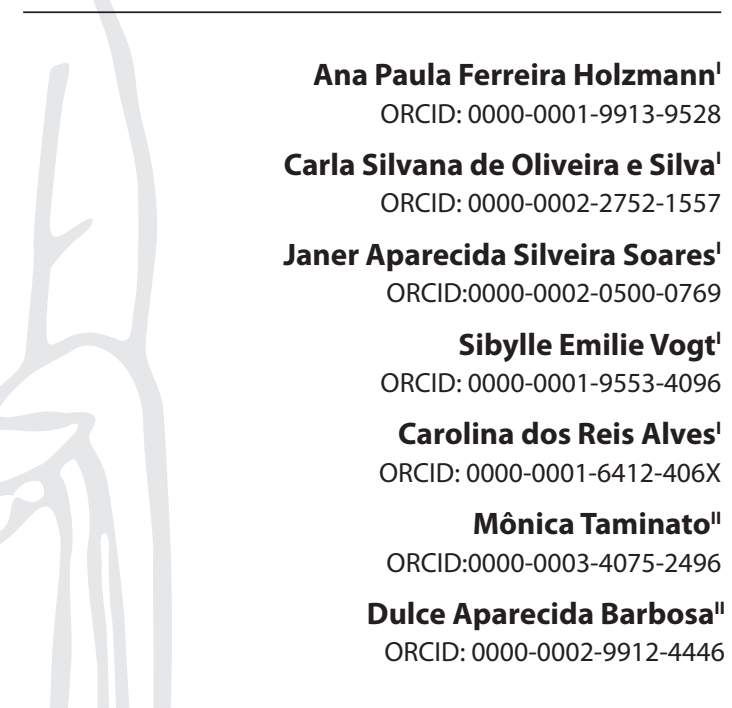

'Universidade Estadual de Montes Claro. Montes Claros, Minas Gerais, Brazil.

"Universidade Federal de São Paulo. São Paulo, São Paulo, Brazil.

How to cite this article: Holzmann APF, Silva CSO, Soares JAS, Vogt SE, Alves $C R$, Taminatto $M$, et al. Preventing vertical HIV virus transmission: hospital care assessment. Rev Bras Enferm. 2020;73(3):e20190491 doi: http://dx.doi.org/10.1590/0034-7167-2019-0491

Corresponding author: Ana Paula Ferreira Holzmann E-mail:apaulah@uol.com.br

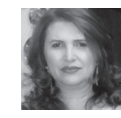

EDITOR IN CHIEF: Antonio José de Almeida Filho ASSOCIATE EDITOR: Priscilla Valladares Broca

Submission: 06-25-2019

Approval: 10-30-2019

\section{ABSTRACT}

Objectives: assess the implementation of actions to prevent vertical transmission of HIV. Methods: a retrospective cohort study conducted in two maternity hospitals in the city of Montes Claros, State of Minas Gerais. All women admitted for childbirth diagnosed with HIV and their respective newborns were included from 2014 to 2017. Data were collected from medical records and analyzed descriptively. Results: population consisted of 46 pairs of mothers and newborns. Management was considered inadequate in 30 cases of parturient/postpartum women (65.2\%) and 14 cases of newborns (30.4\%). The main reasons for inadequate maternal management were lack of pharmacological inhibition of lactation (53.3\%) and counseling/consent for HIV testing (43.3\%). For newborns, late onsetoffirst dose ofZidovudine $(50.0 \%)$ and no prescriptionofNevirapine (28.6\%). Conclusions: important prevention opportunities were missed, pointing to the need for improved care.

Descriptors: Infectious Disease Transmission, Vertical; HIV; Prevention and Control; Health Services Research; Hospitals.

\section{RESUMO}

Objetivos:avaliar a implementação das ações de prevenção da transmissão vertical do HIV. Métodos:estudo de coorte retrospectivo, realizado em duas maternidades de Montes Claros, Minas Gerais. Foram incluídas todas as mulheres admitidas para o parto com diagnóstico de HIV e seus respectivos recém-nascidos, nos anos de 2014 a 2017. Os dados foram coletados de prontuários e analisados de forma descritiva. Resultados: a população foi composta por 46 pares de mães e recém-nascidos. O manejo foi considerado inadequado em 30 casos de parturientes/puérperas $(65,2 \%)$ e em 14 casos de recém-nascidos $(30,4 \%)$. Os principais motivos para a inadequação do manejo materno foram: ausência da inibição farmacológica da lactação $(53,3 \%)$ e do aconselhamento/consentimento na realização do exame anti-HIV (43,3\%). Para os recém-nascidos, início tardio da primeira dose daZidovudina (50,0\%) e não prescrição da Nevirapina (28,6\%). Conclusões:oportunidades importantes de prevenção foram perdidas, apontando para a necessidade de melhoria da assistência.

Descritores: Transmissão Vertical de Doença Infecciosa; HIV; Prevenção e Controle; Avaliação de Serviços de Saúde; Hospitais.

\section{RESUMEN}

Objetivos: evaluar la implementación de acciones para prevenir la transmisión vertical del $\mathrm{VIH}$. Métodos:estudio de cohorte retrospectivo realizado en dos hospitales de maternidad em la ciudad de Montes Claros, estado de Minas Gerais. Todas las mujeres ingresadas para el parto diagnosticadas con VIH y sus respectivos reciénnacidos se incluyeron entre 2014 y 2017. Los datos se recopilaron de los registros médicos y se analizaron descriptivamente. Resultados: la población consistió en 46 pares de madres y reciénnacidos. El manejo se consideró inadecuado en 30 casos de mujeres parturientas/posparto $(65,2 \%)$ y 14 casos de reciénnacidos $(30,4 \%)$. Las razones principales para el manejo materno inadecuado fueron: falta de inhibición farmacológica de lalactancia $(53.3 \%)$ y asesoramiento/consentimiento para la prueba del VIH (43,3\%). Para los reciénnacidos, inicio tardío de la primera dosis de zidovudina $(50.0 \%)$ y sin prescripción de nevirapina $(28,6 \%)$. Conclusiones: se perdieron importantes oportunidades de prevención, lo que indica la necesidad de una mejor atención. Descriptores:Transmisión Vertical de Enfermedad Infecciosa; VIH; Prevención y Control; Investigación sobre Servicios de Salud; Hospitales. 


\section{INTRODUCTION}

Sexually transmitted infections (STIs) have a major impact on global public health.In this setting, the spread of Human Immunodeficiency Virus (HIV) infection stands out due to its infectious capacity, its biological complexity, deleterious repercussion on the immune system of the affected, difficulty in control and treatment, social stigma, and its high cost for health care ${ }^{(1-2)}$.

Due to its diversity of forms of transmission (blood, sexual and vertical) and the sociocultural and epidemiological changes that have occurred in recent decades, HIV infection has indiscriminately affected the world population, with a major impact on women's health. In Brazil, this phenomenon, called feminization of the epidemic, caused a change in the infection profile from a ratio of 28:1 (men:women) in 1985 to less than 3:1, currently ${ }^{(3-4)}$.

Feminization, coupled with the increased prevalence of infection in people of reproductive age, has led to increased rates of motherto-child transmission of the virus, also called vertical transmission (VT). Considered as the main form of HIV infection in children, VT can occur during pregnancy, childbirth or breastfeeding, with a higher risk of transmission during labor and delivery ${ }^{(4,5)}$

In Brazil, from 2000 to June 2018, 116,292 HIV-infected pregnant women were reported, $38.6 \%$ of them living in the Southeast region. In the last ten years there has been a $21.7 \%$ increase in case detection rate in pregnant women in the country and, at the same time, a downward trend in cases of virus VT. The explanation for these facts is based on the increase in prenatal diagnosis and consequent improvement in the prevention of VT of HIV (3).

Early initiation of combination antiretroviral therapy (CART) for infected pregnant women associated with elective caesarean section, perinatal drug prophylaxis and breastfeeding suppression is the best combination for reducing $\mathrm{VT}^{(6-8)}$. These measures are recommended and made available by Brazil's MoH. When recommendations are followed, VT reaches rates of $1 \%$ to $2 \%(4,9)$.

Despite evidence of the effectiveness of VT of HIV prophylaxis measures and all government investments already made in projects, programs and campaigns, the elimination of this problem remains a challenge for Brazil's health policies. Brazil is among the countries that have not yet reached the Pan American Health Organization (PAHO) and World Health Organization (WHO) target to reduce virus VT to less than two cases for every 100 infected mothers ${ }^{(10-13)}$.

According to Domingues et al. ${ }^{(14)}$, cases of VT continue to occur in the country due to failures in various sectors and may involve both health professionals and their respective services and managers as well as the users themselves. Therefore, knowing the local reality is the first step, from the identification of the faults and actors involved, to assess the problematic situations and to propose ways to solve them.

Given the epidemiological scenario presented and considering that VT of HIV remains a public health problem despite its preventable character, we were motivated to conduct this study.

\section{OBJECTIVES}

To assess the implementation of actions to prevent VT of HIV in two maternity hospitals in the city of Montes Claros, State of Minas Gerais.

\section{METHODS}

\section{Ethical aspects}

The study was approved by the Research Ethics Committee of the Universidade Federal de São Paulo.It meets the ethical aspects defined by the Brazilian National Health Board (CNS ConselhoNacional de Saúde) through Resolution 466/2012 that regulates the research involving human beings.

\section{Design,place and period of study}

This is an observational retrospective cohort study guided by STROBE (Strengthening the Reporting of Observational Studies in Epidemiology) checklist tool ${ }^{(15)}$.

It was performed at the maternity hospitals of the two largest hospitals in the city of Montes Claros, based in the northern region of Minas Gerais. Both are affiliated to the Brazilian Unified Health System (SistemaÚnico de Saúde). They serve as a reference for high-risk pregnant women and have the title of Safe Motherhood, in addition to being accredited to the Child-Friendly Hospital initiative (HAC - Hospital Amigo da Criança). Together they attend a mean of 540 deliveries per month and also perform academic teaching and research activities linked to Undergraduate and Graduate Higher Education Institutions, including residency in gynecology/obstetrics and pediatrics. The data collected refer to the period from 2014 to 2017.

\section{Population andinclusion criteria}

The study population was composed of the universe of women admitted to attend childbirth in the referred maternity hospitals from 2014 to 2017 and their respective newborns (NB).

Eligible cases were those whose women were identified with a diagnosis of HIV in pregnancy, childbirth or postpartum who had their live births delivered. As the prevalence of HIV infection in pregnant women is low, it was decided to analyze all cases.

\section{Study protocol}

Data were collected from medical records of women and their NB. Information not found in medical records was sought in the SINAN declarations of live births and reporting forms (HIV in pregnant women and exposed children). The tool used was a form adapted from the questionnaire adopted by Macêdo ${ }^{(16)}$.

The variables of interest for the analysis of care management were extracted from care protocols of Brazil's MoHand include information on prenatal care, delivery and postpartum care, as well as on NBs, as well as maternal characteristics.

The collected data were entered twice using a database created in the Epidata, version 3.0 program, which was later corrected and transferred to the SPSS, version 19.0 program, where the data were analyzed descriptively.

\section{Analysis of results, and statistics}

For the description of qualitative variables, the statistics presented were absolute frequencies ( $n$ ) and relative frequencies 
(\%). For the description of quantitative variables, the mean as central measure and standard deviation, minimum and maximum to indicate the variability were presented.

In order to define the adequacy of hospital management of parturient/postpartum women and NBs exposed, the implementation of prophylaxis measures recommended by the MoH was used as gold standard. They are available in the Clinical Protocol and Therapeutic Guidelines in force at the time of the occurrence of the researched cases ${ }^{(2,4,17)}$, namely: 1) Performing the rapid test (RT) for HIV on admission for delivery, when necessary, i.e., for those pregnant women without previous diagnosis or without proof of it; 2) Counseling and consent of the pregnant woman to perform the RT; 3) Intravenous (IV) Zidovudine (AZT) administration during labor and delivery; 4) AZT EV infusion time for at least 3 hours; 5) Acceptable choice of delivery; 6) Pharmacological inhibition of lactation; 7) Antiretroviral therapy (ARV) administration in the NB (oral AZT and Nevirapine, when indicated); 8) Initiation of oral AZT in the first 4 hours of life and Nevirapine in the first 48 hours of life; 9) Report of women diagnosed in the maternity ward and of exposed children; 10) Referral of the binomial mother and child for outpatient follow-up.

It is noteworthy that the management was considered adequate only when all the recommended conducts were performed and properly registered in medical records. From this, the hospital management of both women and NBs was analyzed in relation to the independent variables of interest.

\section{RESULTS}

During the study period, there were 25,824 deliveries in the maternity hospitals surveyed, 7,680 (29.7\%) in maternity A and 18,144 in maternity B (70.3\%). Among these, 46 cases of women admitted for childbirth who were diagnosed with HIV were identified, 42 cases in maternity A (91.3\%) and four cases in maternity $B(8.7 \%)$. All deliveries resulted in live births, making up a population of 46 mother-child binomials.

Regarding sociodemographic data, most of them were married or in a stable union (65.2\%), non-white $(97.7 \%)$, with eight years or less of completed studies (54.8\%). without paid occupation (61.3\%), coming from Montes Claros (71.7\%) and the urban area (89.1\%). The mean age was 30.2 years, with a minimum of 19 and a maximum of 48 years $(S D=7.1)$ and a predominant age group of 25 years or older (71.7\%) (Data not shown in table).

Most women were multiparous (73.9\%), with a mean of three pregnancies $(\mathrm{SD}=1.8)$ and progressing to at least one abortion in $31.6 \%$ of cases. Almost all had prenatal care (95.7\%) and more than half had six or more visits (58.1\%), with at least one and at most ten (mean of 5.6). Had a diagnosis of HIV infection before (54.3\%) or during pregnancy (32.6\%). Regarding VT prophylaxis, $87.2 \%$ of pregnant women received ARV treatment (Data not shown in table).

At admission for delivery, most women had full-term pregnancies (84.8\%), with a gestational age (GA) of at least 27 and a maximum of 41 weeks (mean of 38; $S D=2.2$ ), less than four $\mathrm{cm}$ of cervical dilation (67.4\%), intact amniotic sac (68.2\%) and, when rotated, mean rupture time of five hours $(S D=3.9)$ (Data not shown in table).
Table 1-Hospital management of pregnant women/parturient/mothers diagnosed with HIV and newborns exposed to infection in two maternity hospitals in Montes Claros, Minas Gerais, Brazil, 2014 to 2017

\begin{tabular}{|c|c|c|}
\hline Variables & $\mathbf{n} *$ & $\%$ \\
\hline \multicolumn{3}{|l|}{ Rapid HIV test (RT) ( $\mathrm{n}=46)$} \\
\hline Yes & 16 & 34.7 \\
\hline No & 20 & 65.3 \\
\hline \multicolumn{3}{|l|}{ RT time $(n=16)$} \\
\hline At pre-delivery & 15 & 93.8 \\
\hline At postpartum & 1 & 6.2 \\
\hline \multicolumn{3}{|l|}{ RT counseling and consent registry $(n=16)$} \\
\hline Yes & 3 & 18.8 \\
\hline No & 13 & 81.2 \\
\hline \multicolumn{3}{|c|}{ Examination of viral load available at delivery $(n=40)$} \\
\hline Yes & 25 & 62.5 \\
\hline No & 15 & 37.5 \\
\hline \multicolumn{3}{|l|}{ Viral Load Value $(n=25)$} \\
\hline Undetectable & 11 & 44.0 \\
\hline Less than 1,000 copies & 8 & 32.0 \\
\hline Equal or greater than 1,000 copies & 6 & 24.0 \\
\hline \multicolumn{3}{|c|}{ Use of intravenous AZT in labor/delivery $(n=46)$} \\
\hline Yes & 40 & 87.0 \\
\hline No & 6 & 13.0 \\
\hline \multicolumn{3}{|l|}{ AZT infusion time until delivery $(n=40)$} \\
\hline Lessthan3 hours & 7 & 17.5 \\
\hline 3 hours or more & 33 & 82.5 \\
\hline \multicolumn{3}{|l|}{ Type of delivery $(n=46)$} \\
\hline Vaginal & 11 & 23.9 \\
\hline Cesarean & 35 & 76.1 \\
\hline \multicolumn{3}{|l|}{ Indication for cesarean section $(\mathrm{n}=35)$} \\
\hline HIV elective & 24 & 68.6 \\
\hline Labor in women HIV + & 4 & 11.4 \\
\hline Other obstetric indication & 7 & 20.0 \\
\hline \multicolumn{3}{|c|}{ Performance of mechanical inhibition of lactation $(n=45)$} \\
\hline Yes & 41 & 91.1 \\
\hline No & 4 & 8.9 \\
\hline \multicolumn{3}{|c|}{ Performance of chemical inhibition of lactation $(n=44)$} \\
\hline Yes & 30 & 68.2 \\
\hline No & 14 & 31.8 \\
\hline \multicolumn{3}{|l|}{ Referenced postpartum $(n=46)$} \\
\hline Yes & 44 & 95.6 \\
\hline No & 2 & 4.4 \\
\hline \multicolumn{3}{|c|}{ Reported cases (HIV in pregnant women) $(n=46)$} \\
\hline Yes & 45 & 97.8 \\
\hline No & 1 & 2.2 \\
\hline \multicolumn{3}{|l|}{ Prescription drug for NB $(n=46)$} \\
\hline Oral AZT & 20 & 43.5 \\
\hline Oral AZT + Nevirapine & 26 & 56.5 \\
\hline \multicolumn{3}{|c|}{ Beginning of oral AZT administration $(n=44)$} \\
\hline Up to 4 hours of life & 37 & 84.1 \\
\hline 4 hours or more of life & 7 & 15.9 \\
\hline \multicolumn{3}{|c|}{ Beginning of Nevirapine administration $(n=26)$} \\
\hline Up to 48 hours of life & 26 & 100.0 \\
\hline \multicolumn{3}{|l|}{ Reported Cases (HIV-exposed NB) $(n=46)$} \\
\hline Yes & 45 & 97.8 \\
\hline No & 1 & 2.2 \\
\hline \multicolumn{3}{|l|}{ NB referenced $(n=46)$} \\
\hline Yes & 45 & 97.8 \\
\hline No & 1 & 2.2 \\
\hline
\end{tabular}


Regarding hospital care (Table 1), it is noteworthy that the rapid test was performed in less than half of women. Of these, only three were counseled and signed the consent form for the test, according to the medical records. Viral load screening was available in $62.5 \%$ of cases and undetectable in $44 \%$.

All NBs used oral zidovudine and most started the medication less than four hours of life. Nevirapine, when used, was started less than 48 hours of age in all cases. Finally, mothers and children were mostly reported and referred for outpatient follow-up after discharge (Table 1).

Regarding the assessment of the management adopted at the hospital level (Table 2), it was found that there was a lower frequency of NB management failures when compared to the management of parturient/postpartum women.The main reasons identified for the inadequate management of women were: lack of pharmacological inhibition of lactation, lack of counseling and consent for HIV testing and IV AZT administration for less than 3 hours. Regarding the management of NBs, the late initiation of administration of oral AZT solution and the lack of prescription or unnecessary prescription of Nevirapine were highlighted (Table 2).

When relating the adequacy of hospital management to the other variables of interest, it was observed that maternal management prevailed as inadequate for most categories of variables analyzed, except for color/race and diagnosis of HIV during pregnancy.

The opposite was observed in relation to NB, where adequate management was more frequent for all categories of variables analyzed (Table 3).

\section{DISCUSSION}

The analysis of the sociodemographic profile of the investigated women corroborates findings from other studies and reinforces the theory of pauperization and internalization of the HIV epidemic ${ }^{(3,18-20)}$. The fact that the majority is married/cohabiting brings us to gender issues, still marked by factors that contribute to greater female vulnerability, such as the trust placed in a stable relationship and the male sexual imposition. This imposition usually excludes the possibility of condom use, especially in conjugal contexts ${ }^{(20-21)}$.

Considering the limitations of prenatal care, also evidenced in this study, the moment of childbirth, the main object of this investigation, is seen as a second opportunity for diagnosis and intervention to reduce VT of HIV, especially in countries such as Brazil. Most births occur in a hospital setting ${ }^{(22)}$.

In this study, all women not diagnosed or tested during pregnancy $(n=6 ; 13.0 \%)$ underwent RT at admission for delivery, as

Note: *Valid data.
Table 2 - Reasons for inadequate hospital management of parturient/ postpartum women diagnosed with HIV and exposed newborns, in two maternity hospitals in Montes Claros, Minas Gerais, Brazil, 2014 to 2017

\begin{tabular}{lcc}
\hline Inadequate Management & n* & $\%$ \\
\hline Parturient/postpartum women ( $\mathrm{n}=30 ; 65.2 \%)$ & & \\
Insufficient IV AZT time during labor/delivery (<3hs) & 7 & 23.3 \\
IV AZT prophylaxis during unperformed labor/delivery & 6 & 20.0 \\
Pharmacological inhibition of lactation not performed & 16 & 53.3 \\
Counseling not accomplished/registered & 13 & 43.3 \\
Consent to RT unsolicited/registered HIV & 13 & 43.3 \\
Postpartum rapid HIV test & 1 & 3.3 \\
Inadequate type of delivery & 1 & 3.3 \\
Case not referred for outpatient follow-up & 1 & 3.3 \\
Casenotreported & 1 & 3.3 \\
Newborns (n=14; $30.4 \%)$ & & \\
Late start of AZT (> 4 hrs) & 7 & 50.0 \\
Nevirapine prophylaxis required but not performed & 4 & 28.6 \\
Nevirapine prophylaxis performed, but unnecessary & 2 & 14.3 \\
Case not referred for outpatient follow-up & 1 & 7.1 \\
Case not reported & 1 & 7.1 \\
\hline
\end{tabular}

Table 3 -Classification of hospital management according to maternal characteristics, time of HIV diagnosis, prenatal care, viral load, cervical dilation, integrity of amniotic membranes and type of delivery, 2014 to 2017

\begin{tabular}{|c|c|c|c|c|}
\hline \multirow{3}{*}{ Variables } & \multicolumn{4}{|c|}{ Management } \\
\hline & \multicolumn{2}{|c|}{ Maternal } & \multicolumn{2}{|c|}{ NB } \\
\hline & $\begin{array}{c}\text { Adequate } \\
\mathrm{n}^{*}(\%)\end{array}$ & $\begin{array}{c}\text { Inadequate } \\
\mathbf{n}^{*}(\%)\end{array}$ & $\begin{array}{c}\text { Adequate } \\
n^{*}(\%)\end{array}$ & $\begin{array}{c}\text { Inadequate } \\
\mathbf{n}^{*}(\%)\end{array}$ \\
\hline \multicolumn{5}{|l|}{ Maternal age $(n=46)$} \\
\hline$<25$ years & $6(46.2)$ & $7(53.8)$ & $9(69.2)$ & $4(30.8)$ \\
\hline$\geq 25$ years & $10(30.3)$ & $23(69.7)$ & $23(69.7)$ & $10(30.3)$ \\
\hline \multicolumn{5}{|l|}{ Marital status $(n=46)$} \\
\hline Married & $9(30.0)$ & $21(70.0)$ & $21(70.0)$ & $9(30.0)$ \\
\hline Single & $7(43.8)$ & $9(56.2)$ & $11(68.8)$ & $5(31.2)$ \\
\hline \multicolumn{5}{|l|}{ Education ( $n=42)$} \\
\hline$>8$ years & $7(30.4)$ & 16(69.6) & 13(68.4) & $6(31.6)$ \\
\hline$\leq 8$ years & $7(36.8)$ & $12(63.2)$ & $17(73.9)$ & $6(26.1)$ \\
\hline \multicolumn{5}{|l|}{ Race/Color $(n=43)$} \\
\hline White & $1(100.0)$ & $0(0.0)$ & $1(100.0)$ & $0(0.0)$ \\
\hline Non-white & $13(31.0)$ & $29(69.0)$ & $29(69.0)$ & $13(31.0)$ \\
\hline \multicolumn{5}{|l|}{ Diagnosis time $(n=46)$} \\
\hline Before pregnancy & $6(24.0)$ & 19(76.0) & $18(72.0)$ & $7(28.0)$ \\
\hline During pregnancy & $10(66.7)$ & $5(33.3)$ & $11(73.3)$ & $4(26.7)$ \\
\hline Birth/postpartum & $0(100.0)$ & $6(100.0)$ & $3(50.0)$ & $3(50.0)$ \\
\hline \multicolumn{5}{|l|}{ Prenatal care $(n=46)$} \\
\hline Yes & $16(36.4)$ & $28(63.6)$ & $30(68.2)$ & 14(31.8) \\
\hline No & $0(0.0)$ & $2(100.0)$ & $2(100.0)$ & $0(0.0)$ \\
\hline \multicolumn{5}{|c|}{ Examination available viral load $(n=40)$} \\
\hline Yes & $12(48.0)$ & $13(52.0)$ & $17(68.0)$ & $6(32.0)$ \\
\hline No & $4(26.7)$ & $11(73.3)$ & $12(80.0)$ & $3(20.0)$ \\
\hline \multicolumn{5}{|l|}{ Cervical dilation $(n=44)$} \\
\hline$<4 \mathrm{~cm}$ & $13(43.3)$ & 17(56.7) & $18(60.0)$ & $12(40.0)$ \\
\hline 4to $6 \mathrm{~cm}$ & $2(22.2)$ & $7(77.8)$ & $9(100.0)$ & $0(0.0)$ \\
\hline $7-10 \mathrm{~cm}$ & $1(20.0)$ & $4(80.0)$ & $4(80.0)$ & $1(20.0)$ \\
\hline \multicolumn{5}{|l|}{ Water bag $(n=45)$} \\
\hline Full & $14(45.2)$ & $17(54.8)$ & $21(67.7)$ & $10(32.3)$ \\
\hline Route & $2(14.3)$ & $12(85.7)$ & $10(71.4)$ & $4(28.6)$ \\
\hline \multicolumn{5}{|l|}{ Type of delivery $(n=46)$} \\
\hline Vaginal & $3(27.3)$ & $8(72.7)$ & $8(72.7)$ & $3(27.3)$ \\
\hline Cesarean & 13(37.1) & $22(62.9)$ & $24(68.6)$ & $11(31.4)$ \\
\hline
\end{tabular}


standardized, except for one, whose test was only performed at postpartum, although hospitalization occurred at the beginning of labor. Examination was also performed, "unnecessarily", in 10 women who already had a previous diagnosis of infection (21.7\%), probably due to the lack of proof at the time of admission.

It is noteworthy that, in any situation of HIV testing, women should receive pre- and post-test counseling from trained health professionals. Examination should always be performed upon consent and record in the medical record ${ }^{(2,4)}$.This was observed only in three cases (18.8\%) in the maternity hospitals surveyed. A study carried out by Passos et al. ${ }^{(23)}$, which investigated counseling in five HACs in the city of Rio de Janeiro, found a $25 \%$ prevalence of counseling. In the city of Recife, the result was worse, with only $7.7 \%$ of parturient women being advised during testing ${ }^{(24)}$. The low prevalence in our study raises criticisms regarding the qualification and assessment of nursing care, since performing the RT is a function assigned to these professionals in both hospitals.

Factors associated with the risk of VT include maternal viral load (VL). The value is used as a reference for the definition of conducts, as a prescription for ARV regimen for pregnant women and parturient women, and also for the definition of the type ofdelivery $^{(4,25)}$. Despite its importance, information about the examination was not found in $37.5 \%$ of the medical records.

About prophylaxis during labor, it was found that among the six women (13.0\%) who did not receive IVAZT, three cases (50\%) are justified by admission already in expulsive period. This is not true for the others, as two of them were at the beginning of the active phase of labor when admitted and the other was only diagnosed late in the postpartum, despite being less than $4 \mathrm{~cm}$ dilated at admission. It is noteworthy that there was a serious operational failure in one of the above cases, in which AZT was not released by the pharmacy in time to be administered, as recorded in the medical record.

Another shortcoming observed is the AZT infusion time, which is recommended for a minimum of three hours, which is the period necessary to reach the appropriate intracellular drug concentration, which should be maintained until the umbilical cord is ligated $^{(7,26)}$. Among the seven parturient women (18.5\%) who received AZT for less than three hours, only one of them admitted to advanced labor ( $9 \mathrm{~cm}$ of cervical dilation). In addition, all had a diagnosis of HIV prior to hospitalization, five of them undergoing cesarean section for this reason, which theoretically makes it inadmissible not to follow all recommendations.

It is noteworthy that the admission of women in advanced labor has been described as one of the main obstacles linked to the failure to administer AZT before and during delivery. This period could be alleviated with the counseling of pregnant women during prenatal care about the need to seek immediate care in the face of signs of labor or loss of amniotic fluid. This would prevent a lack of timely intervention ${ }^{(27)}$.

Regarding the type of delivery, our findings corroborate other studies in which the majority of deliveries in women with HIV (35; $76.1 \%)$ were cesarean ${ }^{(18,25-28)}$.

Importantly, cesarean section should not be seen as a rule. Vaginal delivery can also be safely performed in HIV-positive women as long as clinical and obstetric conditions are observed, in addition to the value of $\mathrm{VL}$, which should be undetectable or less than 1,000 copies/m during last trimester examination ${ }^{(4,18,25)}$.
In this study, according to available VL parameters, it was found that ten women (33.3\%) who underwent cesarean section could have evolved to normal delivery. However, considering that the type of delivery in these situations does not change the risk of VT and that this is a decision that can be discussed between the obstetrician and the pregnant woman ${ }^{(2,4,29)}$, it was decided not to assess the adequacy of the type of delivery when it occurred operatively.

On the other hand, as already demonstrated the benefit of elective cesarean section or early labor when maternal viral load is unknown or greater than 1,000 copies $/ \mathrm{ml}^{(2,3,7)}$, it was concluded that, among the eleven vaginal deliveries, two (18.2\%) had indication for cesarean section. However, only one of the cases considered the type of delivery inadequate, since the other parturient woman arrived in the expulsive period, although she already had a previous diagnosis of the infection.

After delivery, a new stage of interventions begins, now aimed at NBs. As in the management of parturient women, failures were also observed in the administration of ARV medication in NBs, including some considered inadmissible as late administration of oral AZT in six children (11.1\%), whose mothers were already known to be HIV-positive. Another case was found, however, the delay occurred as a result of the late diagnosis of the woman (postpartum), another previously reported failure. According to the recommendations, the first dose of the drug should be administered already in the delivery room after the first NB care, or at the latest 4 hours after birth ${ }^{(25-26)}$.

Nevirapine use should be indicated in combination with AZT when the risk of VT is higher. That is, for all NBs, 35 weeks or older, born to mothers who did not use ARV medication during pregnancy or who did not achieve sustained VL suppression in the last trimester ${ }^{(30-32)}$. This recommendation was based on a clinical trial (Protocol 1043) that showed a significant reduction in VT in the two-drug versus one-drug regimen group ${ }^{(33)}$.

In the present study, four cases were identified in which Nevirapine was not prescribed, although indicated. Inverse situation was also verified, where Nevirapine was prescribed without indication, denouncing, once again, the lack of professional preparation.

The last step for intervention for VT of HIV prophylaxis, as important as the previous ones, concerns breastfeeding that should be contraindicated regardless of maternal plasma $V L$, since mother's use of ARV is not effective to control elimination of HIV through breast milk, therefore not guaranteed protection ${ }^{(34)}$. Thus, it is recommended that every woman living with HIV/AIDS be advised not to breastfeed, and informed about the right to receive infant formula for at least six months ${ }^{(4,35-36)}$.

In addition to counseling on non-breastfeeding, inhibition of lactation should be initiated soon after delivery, preferably by administering carbegoline, which is more effective and convenient than other medications. On the other hand, mechanical inhibition through breast bandaging, due to its questionable effectiveness and low adhesion, mainly due to the discomfort and embarrassment caused, should only be performed in the absence of pharmacological lactation inhibitors ${ }^{(2,35-36)}$.

It is noteworthy that the purchase of pharmacological inhibitors, such as carbegoline, is reimbursed to hospitals by the government. Thus, it is up to the services to organize themselves to offer the 
medication to women before hospital discharge, which did not occur in many situations in this study(31.8\%). There was also a resistance to abandon the mechanical inhibition method of lactation, since, even though receiving pharmacological inhibition, many women also had their breasts bandaged.

Regarding reporting and referral of cases, there was a greater awareness and attention of professionals regarding the compliance with these steps.

In the present study, prophylaxis measures were adequate and covered all maternal care stages in only $34.8 \%$ of the cases analyzed. Less disastrous results were found in relation to NB management, with $69.6 \%$ adequacy. However, when analyzing all steps together, including NB management, the frequency of adequacy falls to $23.9 \%$. Weaknesses have been demonstrated along the cascade of interventions that can compromise a child's life, with repercussions on the physical, emotional and social dimensions.

The highest frequency of inadequate maternal management was observed in all categories of sociodemographic variables analyzed, except for skin color, where failures were observed only in non-white women. This vulnerability related to skin color is also evident in other studies by identifying that these women, in addition to being proportionally more infected, are also less favored, not only in the diagnosis of infection but also in the adoption of prophylaxis measures in all care stages ${ }^{(19,37)}$.

It was noteworthy that the highest concentration of inadequate management occurred among women diagnosed with HIV before pregnancy. This group was expected to benefit most, as the effectiveness of prophylaxis measures is based on early knowledge of the infection ${ }^{(2,4)}$.

Among prenatal women, hospital management was also inadequate in most cases. In the context of women living with the HIV virus, prenatal care is expected to reflect on the quality of hospital care, especially through awareness and counseling of pregnant women regarding VT prophylaxis and its stages, making them more aware, attentive and active in the process.

As expected, it was observed that, among women admitted with lower cervical dilation, the frequency of adequacy of management was higher and failures increased as cervical dilation was also higher at admission. This fact reiterates that women's entry into maternity at an early stage of labor contributes to reducing the occurrence of failures through the longer time available for intervention, especially in the maternal stages of prophylaxis.

Although the highest frequency of inadequate management occurred regardless of the characteristic of the amniotic pouch and type of delivery, it was found that women with intact pouch and those who underwent cesarean section lost less chances of prevention, certainly due to the higher occurrence of scheduled surgeries in these cases.

Given the situations presented, it can be seen that opportunities for prevention were missed and at one of the most risky times for VT, which could be avoided, if all recommended measures are met.

Several studies conducted by Brazil, with similar objectives to this one, unfortunately corroborate our results ${ }^{(19,38-40)}$. An international study, conducted in the United States in 15 US jurisdictions from 2005 to 2008, also identified the loss of at least one prevention opportunity in half of all births during the period ${ }^{(41)}$.
If there is interest in national health policies, availability of inputs and care protocols that guide the actions of professionals, why do we continue to fail in the goal of eliminating VT? This is a question that has been attended by several studies and whose answers go through several hypotheses. Among them is the lack of management of services and training of professionals involved in care, from prenatal care to hospital care at birth, as well as issues related to women's individual and social vulnerability ${ }^{(10-14,19,39-40)}$.

Cuba's success is proof that even in countries with limited financial resources, the elimination of VT of HIV can become a reality as long as investments are made. Investments not only in coverage but also in the quality of services, in addition to maintaining a well-organized and effective national surveillance system ${ }^{(42)}$.

\section{Study limitations}

Secondary data searches are subject to the quality of records that are often deficient due to incomplete or inadequate information completion. In addition, consideration should be given to the possibility that procedures were performed and not registered in the medical records, which also limits the study's conclusions.

\section{Contributions to nursing, health, and public policy}

From the reality found, the professionals involved in care can reflect on their role and co-responsibility in the occurrence of such a serious and preventable outcome. For managers, the findings may contribute to raising awareness about the social responsibility of the titles of "Safe Motherhood" and "HAC". These titles are attributed to the investigated institutions and, consequently, to the decision-making process in search of care that is truly compatible with the company's law.

\section{CONCLUSIONS}

The results of this study indicated inadequacies in care management of the studied population, indicating failures in following the guidelines and recommendations for VT of HIV prophylaxis in force in the country, ranging from prenatal care to delivery and NB care.

The analysis of the contexts in which hospital interventions were not timely or adequately performed indicates that most of the occurrences could have been avoided. They are lack of counseling, failure to administer AZT at delivery, low utilization of pharmacological inhibition of lactation, delayed release and or administration of medications. All the faults indicated indicate weaknesses in the organization of services and management of mother-child binomials, compromising the effectiveness of preventive actions.

Such facts are considered serious, especially when they occur in teaching and referral hospitals for high-risk pregnant women care and, therefore, need to have their causes investigated and promptly corrected.

Investing in work process management and continuing education for care professionals, including training in counseling and clinical management, is believed to be one of the pathways that, in the current scenario, best achieves the goal of eliminating VT of HIV. 


\section{REFERENCES}

1. Mayer KH, Pape JW, Wilson P, Diallo DD, Saavedra J, Mimiaga MJ, et al. Multiple determinants, common vulnerabilities, and creative responses: addressing the AIDS pandemic in diverse populations globally. JAIDS 2012;60(Suppl 2):S31-34. doi: 10.1097/QAI.0b013e31825c16d9

2. Ministério da Saúde (BR). Secretaria de Vigilância em Saúde. Departamento de DST, Aids e Hepatites Virais. Protocolo clínico e diretrizes terapêuticas para Atenção Integral às Pessoas com Infecções Sexualmente Transmissíveis [Internet]. Brasília (DF): Ministério da Saúde; 2015 [cited 2017 Jun 13]. Available from: http://bvsms.saude.gov.br/bvs/publicacoes/protocolo_clinico_diretrizes_terapeutica_atencao_integral_ pessoas_infeccoes_sexualmente_transmissiveis.pdf

3. Ministério da Saúde (BR). Secretaria de Vigilância em Saúde. Departamento de Vigilância, Prevenção e Controle das Infecções Sexualmente Transmissíveis, do HIV/Aids e das Hepatites Virais. Boletim Epidemiológico HIV AIDS 2018 [Internet]. Brasília: Ministério da Saúde; 2018 [cited 2019 Feb 29]. Available from: http://www.aids.gov.br/pt-br/pub/2018/boletim-epidemiologico-hivaids-2018

4. Ministério da Saúde (BR). Secretaria de Ciência, Tecnologia e Insumos Estratégicos. Protocolo clínico e diretrizes terapêuticas para Prevenção da Transmissão Vertical de HIV, Sífilis e Hepatites Virais. Relatório de Recomendação [Internet]. Brasília (DF): Ministério da Saúde; 2017 [cited 2017 Nov 19]. Available from: http://conitec.gov.br/images/Consultas/Relatorios/2017/ Relatorio_PCDT_PrevencaoTransmissoVertical_HIV_Sfilis_HepatitesVirais_CP.pdf

5. Fowler MG, Gable AR, Lampe MA, Etima M, Owor M. Perinatal HIV and its prevention: Progress toward an HIV-free generation. Clin Perinatol. 2010;37:699-719. doi.org/10.1016/j.clp. 2010.09.002

6. Nesheim S, Lampe MA, Kilmarx PH, Harris LF, Whitmore S, Griffith J, et al. A Framework for elimination of perinatal transmission of HIV in the United States. Pediatrics. 2012;130(4):738-44. doi:10.1542/peds. 2012-0194

7. Panel on Treatment of HIV-Infected Pregnant Women and Prevention of Perinatal Transmission. Recommendations for use of antiretroviral drugs in pregnant HIV-1-infected women for maternal health and interventions to reduce perinatal HIV transmission in the United States [Internet]. 2018 [cited 2019 Oct 20]. Available from: http://aidsinfo.nih.gov/contentfiles/lvguidelines/PerinatalGL.pdf

8. Luzuriaga K, Mofenson LM. Challenges in the elimination of pediatric HIV-1 infection. N. Engl. J. med. 2016; 374:761-70. doi:10.1056/NEJMra1505256

9. Brasil. Ministério da Saúde. Protocolo Clínico e Diretrizes Terapêuticas para Manejo da Infecção pelo HIV em Crianças e Adolescentes [Internet]. Brasília: Ministério da Saúde; 2014 [cited 2017 Jun 02]. Available from: http://www.aids.gov.br/sites/ default/files/anexos/ publicacao/2013/55308/protocolofinal_31_7_2015_pdf_31327.pdf

10. Secretaria de Estado da Saúde de São Paulo. Coordenadoria de Controle de Doenças. Centro de Referência e Treinamento em DST/AIDS-São Paulo. Programa Estadual de DST/aids-São Paulo. Eliminação da transmissão vertical do HIV e da sífilis no Estado de São Paulo. Rev Saúde Pública. 2011; 45 (4):812-815. doi: 10.1590/S0034-89102011000400026

11. Pan American Health Organization. 2014 Update: Elimination of Mother-to-Child Transmission of HIV and Syphilis in the Americas [Internet]. Washington, DC: PAHO; 2014 [cited 2018 Jun 16]. Available from: http://iris.paho.org/xmlui/handle/123456789/31357

12. Cerda R, Perez F, Domingues RM, et al. Prenatal Transmission of Syphilis and Human Immunodeficiency Virus in Brazil: Achieving Regional Targets for Elimination. Open Forum Infect Dis. 2015; 2 (2):ofv073. doi: /10.1093/ofid/ofv073

13. Pan American Health Organization. 2016 Update: Elimination of Mother-to-Child Transmission of HIV and Syphilis in the Americas [Internet]. Washington, DC: PAHO; 2016 [cited 2018 aug 4]. Available from: http://iris.paho.org/xmlui/handle/123456789/34072

14. Domingues RMSM, Saraceni V, Hartz ZMA, Leal MC. Congenital syphilis: a sentinel event in antenatal care quality. Rev Saúde Pública. 2013; 47(1): 147-157. doi:10.1590/S0034-89102013000100019

15. Von Elm E, Altman DG, Egger M, Pocock SJ, Gøtzsche PC, Vandenbroucke JP, et al. Strengthening the Reporting of Observational Studies in Epidemiology (STROBE statement: guidelines for reporting observational studies. BMJ. 2007; 335(7624):806-8. doi:10.1136/bmj.39335.541782.AD

16. Macêdo, VC. Avaliação da implantação do projeto nascer em maternidades de quatro municípios do Interior do estado de Pernambuco: estudos de casos [Dissertação] [Internet]. Recife: Programa de Pós-Graduação em Saúde Coletiva, Universidade Federal de Pernambuco, 2007. [cited 2016 May 11]. Available from: https://repositorio.ufpe.br/handle/123456789/9511

17. Ministério da Saúde (BR). Secretaria de Vigilância em Saúde. Programa Nacional de DST e Aids. Recomendações para Profilaxia da Transmissão Vertical do HIV e Terapia Antirretroviral em Gestantes [Internet]. Brasília: Ministério da Saúde; 2010. [cited 2018 Dec 15]. Available from: http:// www.aids.gov.br/sites/default/files/consenso_gestantes_2010_vf.pdf

18. Lima ACMACC, Costa CC, Teles LMR, Damasceno AKC, Oriá Mônica Oliveira Batista. Epidemiologic assessment of prevention of vertical transmission of HIV. Acta Paul Enferm. 2014 Aug ; $27(4$ ): 311-318.doi.org/10.1590/1982-0194201400053.

19. Brandão MN, Souza ES, Brito RFV, Guimarães C, Martha MS, Brandão MFR, Cavalcante M C. Challenges in preventing vertical HIV transmission in Petrolina, Pernambuco and Juazeiro, Bahia. Rev Bras Saude Matern Infant[Internet]. 2016[cited 2019 Mar 30];16(3):313-24. Available from: http://www.scielo.br/pdf/rbsmi/v16n3/1519-3829-rbsmi-16-03-0313.pdf

20. Silva CM, Alves RS, Santos TS, Bragagnollo GR, Tavares CM, Santos AAP. Epidemiological overview of HIV/AIDS in pregnant women from a state of northeastern Brazil. Rev Bras Enferm. 2018; 71( Suppl 1): 568-76. doi:10.1590/0034-7167-2017-0495

21. Sousa MCP, Santo ACGE, Motta SKA. Gênero, vulnerabilidade das mulheres ao HIV/AIDS e ações de prevenção em bairro de periferia de Teresina, Piauí, Brasil. Saúde Soc[Internet]. 2008[cited 2012 Jul 03]; 17 (2): 58-68. Available from: http://www.scielo.br/pdf/sausoc/v17n2/07.pdf 
Preventing vertical HIV virus transmission: hospital care assessment Holzmann APF, Silva CSO, Soares JAS, Vogt SE, Alves CR, Taminatto M, et al.

22. Ruschi GEC, Zandonade E, Miranda AE, Antônio FF. Determinantes da qualidade do pré-natal na Atenção Básica: o papel do Apoio Matricial em Saúde da Mulher. Cad Saúde Colet. 2018; 26(2): 131-139. doi: 10.1590/1414-462×201800020229

23. Passos SCS, Oliveira MIC, Saint Jr CSG, Silva KS. Aconselhamento sobre o teste rápido anti-HIV em parturientes. Rev Bras Epidemiol. 2013;16(2): 278-87. doi: 10.1590/S1415-790X2013000200005

24. Morimura MCR, Mendes MDC, de Souza Al, de Alencar LCA. Freqüência de testagem rápida para o HIV durante a admissão para o parto em puérperas no Instituto Materno Infantil Prof. Fernando Figueira, IMIP. Rev Bras Saúde Matern Infant. 2006; 6 (Supl 1): 69-76. doi: 10.1590/ S1519- 38292006000500010

25. Briand N, Warszawski J, Mandelbrot L, Dollfus C, Pannier E, Cravello L, et al. Is intrapartum intravenous zidovudine for prevention of mother-tochild HIV-1 transmission still useful in the combination antiretroviral therapy era? Clin. Infect. Dis. 2013; 57 (6): 903-14. doi: 10.1093/cid/cit374

26. Ministério da Saúde (BR). Secretaria de Vigilância em Saúde. Departamento de Vigilância, Prevenção e Controle das Infecções Sexualmente Transmissíveis, do HIV/Aids e das Hepatites Virais. Protocolo clínico e diretrizes terapêuticas para Prevenção da Transmissão Vertical de HIV, Sífilis e Hepatites Virais [Internet]. Brasília: Ministério da Saúde; 2018 [cited 2019 Feb 29]. Available from: http://www.aids.gov.br/pt-br/ pub/2015/protocolo-clinico-e-diretrizes-terapeuticas-para-prevencao-da-transmissao-vertical-de-hiv

27. Warszawski J, Tubiana R, Le Chenadec J et al. Mother-to-child HIV transmission despite antiretroviral therapy in the ANRS French Perinatal Cohort. AIDS 2008; 22 (2): 289-99. doi:10.1097/QAD.0b013e3282f3d63c

28. Amaral E, Assis-Gomes F, Milanez H, Cecatti JG, Vilela MM, Pinto e Silva JL. Implementação oportuna de intervenções para reduzir a transmissão vertical do HIV: uma experiência brasileira bem-sucedida. Rev Panam Salud Publica [Internet]. 2007 [cited 2018 Jun 10]; 21(6): 357-64. Available from: https://www.scielosp.org/article/rpsp/2007.v21n6/357-364/\#ModalArticles

29. International Perinatal HIV Group. The mode of delivery and the risk of vertical transmission of human immunodeficiency virus type 1 - a meta analysis of 15 prospective cohort studies. N Engl J Med.1999; 340 (13): 977-87. doi:10.1056/NEJM199904013401301

30. Ministério da Saúde (BR). Secretaria de Vigilância em Saúde. Departamento de Vigilância, Prevenção e Controle das Infecções Sexualmente Transmissíveis, do HIV/Aids e das Hepatites Virais. Protocolo clínico e diretrizes terapêuticas para manejo da infecção pelo HIV em crianças e adolescentes [Internet]. Brasília (DF): Ministério da Saúde; 2018 [cited 2019 Jan 8]. Available from: http://www.aids.gov.br/pt-br/pub/2017/ protocolo-clinico-e-diretrizes-terapeuticas-para-manejo-da-infeccao-pelo-hiv-em-criancas-e

31. Dorenbaum A, Cunningham CK, Gelber RD, et al. Two-dose intrapartum/newborn nevirapine and standard antiretroviral therapy to reduce perinatal hiv transmission: a randomized trial. JAMA. 2002; 288(2):189-198. doi: 10.1001/jama.288.2.189

32. Hudgens MG, Taha TE, Omer SB, Jamieson DJ, Lee H, Mofenson LM, et al. Pooled individual data analysis of 5 randomized trials of infant nevirapine prophylaxis to prevent breast-milk HIV-1 transmission. Clin Infect Dis [Internet]. 2013[cited 2019 Jan 22]; 56 (1):131-9. Available from: https://www.ncbi.nlm.nih.gov/pubmed/22997212

33. Nielsen-Saines K, Watts DH, Veloso VG, Bryson, YJ, Joao, E.C, Pilotto, JH, et al. Three postpartum antiretroviral regimens to prevent intrapartum HIV infection. N Engl J Med. 2012; 366 (25): 2368-2379. doi: 10.1056/NEJMoa1108275.

34. Silva MJM, Mendes WS, Gama MEAG, Chein MBC, Veras DS. Perfil clínico-laboratorial de crianças vivendo com HIV/AIDS por transmissão vertical em uma cidade do Nordeste brasileiro. Rev Soc Bras Med Trop [Internet]. 2010 [cited 2018 Dec 12];43(1):32-35. Available from: http://www. scielo.br/pdf/rsbmt/v43n1/a08v43n1

35. Souza FLI. A impossibilidade de amamentar: Sentimentos atribuídos as mães com sorologia positiva para o HIV. Rev Eixos Tech. 2018; 5(1). doi:10.18406/2359-1269

36. Costa A, Vieira B, Alves V, Rodrigues D, Leão D, Pereira A. Nursing care postpartum women seropositive for HIV before the inability to natural breastfeeding. Rev Pesqui Cuid Fundam[Internet]. 2015 [cited 2019 Mar 30]; 7(2): 2310-22. Available from: https://nbn-resolving.org/ urn:nbn:de:0168-ssoar-54240-8

37. Domingues, RM, Szwarcwald, CL, Souza, P R, Leal, M. Prenatal testing and prevalence of HIV infection during pregnancy: data from the "Birth in Brazil" study, a national hospital-based study. BMC Infect Dis. 2015; 15: 100. doi: 10.1186/s12879-015-0837-8

38. Vasconcelos ALR, Hamann EM. Por que o Brasil ainda registra elevados coeficientes de transmissão vertical do HIV? uma avaliação da qualidade da assistência prestada a gestantes / parturientes infectadas pelo HIV e seus recém-nascidos. Rev Bras Saude Matern Infant. 2005; 5(4): 483-492. doi:10.1590/S1519-38292005000400012

39. Lopes DSV. Epidemiologia da transmissão vertical do HIV em Fortaleza, 2002-2005[Dissertação] [Internet]. Rio de Janeiro: Instituto de Comunicação e Informação Científica e Tecnológica/Biblioteca de Saúde Pública; 2008[cited 2017 Jan12]. Available from: https://www.arca. fiocruz.br/handle/icict/4618

40. Lemos LMD, Rocha TFS, Conceição MV, Silva EL, Santos AHS, Gurgel RQ. Evaluation of preventive measures for mother-to-child transmission of HIV in Aracaju, State of Sergipe, Brazil. Rev Soc Bras Med Trop. 2012; 45(6): 682-686. doi:10.1590/S0037-86822012000600005

41. Whitmore S, Taylor A, Espinoza L, Shouse RL, Lampe M, Nesheim S. Correlates of mother-to-child transmission of HIV in the United States and Puerto Rico. Pediatrics. 2012; 129:1-8. doi: 10.1186/s12879-015-0837-8

42. Caffe S, Perez F, Kamb ML, Gomez Ponce de Leon R, Alonso A, et al. Cuba validated as the first country to eliminate mother to child transmission of human immunodeficiency virus and congenital syphilis: lessons learned from the implementation of the global validation methodology. Sex Transm Dis. 2016; 43(12):733-736. doi: 10.1097/OLQ.0000000000000528. 